\title{
Biological Treatment of Lignocellulosic Biomass to Bioethanol
}

\author{
Pramanik K* and Sahu S \\ Department of Biotechnology and Medical Engineering, National Institute of Technology, India
}

Submission: August 03, 2017; Published: August 29, 2017

*Corresponding author: Pramanik K, Department of Biotechnology and Medical Engineering, National Institute of Technology, Rourkela-769008, Orissa, India, Email: mondalkp@gmail.com

\begin{abstract}
This study highlights the biological treatment of lignocellulosic biomass to bioethanol using three major conversion techniques such as pretreatment, hydrolysis and fermentation. Energy from lignocellulosic biomass, especially bioethanol may contribute to a healthy atmosphere and economic development. Bioconversion of sustainable feedstock to bioethanol can enhance the energy dependence of our future generation. Different microbial treatments are summarised here with the recent trend and future aspect. This review article may pave to resolve the challenges on biological processing a reality for the large scale bioethanol production.
\end{abstract}

Keywords: Lignocellulosic biomass; Biological processing; Bioethanol

\section{Introduction}

Due to the depletion of reserve petroleum oil, its rising price, uncertainty in availability and environmental pollution has drawn attention worldwide towards the production of bioethanol as an alternative energy source of transportation fuel [1]. Therefore, in recent years efforts have been put in place to produce bioethanol from lignocellulosic biomass rather than from energy crops because of the consumption of land, water for their growth and rise in cost $[1,2]$. Lignocellulosic biomass consists of cellulose (major component), hemicellulose (complex carbohydrates) and lignin polymer [3,4]. The complex polymer of ligocellulosic biomass can be degrading by different microorganisms due to their potential synergic action of enzymes [5]. It is evident from the literature that biological pretreatment is advantageous over chemical, physicochemical, ammonia and steam explosion pretreatment methods because of the requirement of mild reaction conditions, low energy and formation of minimal toxic by-product $[6,7]$. The conversion of lignonocellulosic biomass to bioethanol is mainly divided into three major steps such as: pretreatment, hydrolysis and fermentation. The conversion techniques follow several biological methods based on different enzymes production for hemicellulose, cellulose and lignin degradation.

\section{Microbial delignification}

Biological pretreatment or so called delignification involves fungi such as white, brown and soft-rot fungi that are used to degrade or decompose complex lignin and solubilize hemicellulose without losing structural sugars [7]. White rot fungi are the most potential strains for the degradation of complex lignin polymer [8]. Most of the mixed cultures of white rot fungi were reported for biodegradation in producing high activity enzymes (ligninase, laccase, manganese peroxidise \& lignin peroxidase) due to their synergistic actions $[9,10]$. Mixed fungal cultures could lead to a higher enzyme production through synergistic interactions, but the final results seem to depend on several factors such as particular species combination or mode of interaction among species, micro-environmental or nutritional conditions in the substrate under colonization [11]. Some of the widely studied white-rot fungi are P. chrysosporium, Pleurotus ostreatus Pycnoporus cinnarbarinus, Trametes pubescens, Cyathus stercolerus and Ceriporiopsis subvermispora which showed high delignification efficiency [12-14]. Several newly isolated microorganisms were also explored to enhance the delignification process [15-17]. Recent review explore on potential delignification of lignocellulosic biomass using genetically engineered fungi $[3,4,18]$. Some bacteria have also been characterized from Azospirillum lipoferum and Bacillus subtilis for delignification [19].

\section{Biodegradation of cellulose and hemicellulose}

This treatment of biomass is carried out to break the carbohydrate polymers to free sugar monomers. This method is known as hydrolysis or saccharification which includes an enzymatic method (fungal and bacterial or commercial enzyme), 
steam explosion, dilute and concentrated acid methods for lignocellulosic biomass have been reported [20,21]. Among this, enzymatic hydrolysis is one of the most suitable options for the conversion of polysaccharide to monosaccharide by avoiding toxic by-product formation. A variety of microorganisms including fungi and bacteria was reported to degrade cellulosic and hemicellulosic biomass to monomer glucose. Due to the complex structure of pentose or hemicellulose, several different enzymes are needed for their enzymatic degradation. The cellulase enzymes employed for the hydrolysis of cellulose to glucose are mainly categorized into three groups: endo-glucanases, exoglucanases, and beta-glucosidases [1]. Hemicellulase and xylanase enzymes are used for the hydrolysis of hemicelluloses [21,22]. The microbial strains of Trichoderma, Aspergillus, Penicillum Altrernaria, Cellulomonas, Streptomyces, Bacteriodes and Bacillus are reported to produce efficient enzymes such as xylanase, hemicellulase, lingnocellulolytic activity (synergic effects of cellulolytic and lignolytic) and hemicellulolytic activity for potential hydrolysis to improve ethanol production [23,24] Researcher are developed some mutant or genetically modified fungal and bacterial strains for cellulose and hemicellulose degradation [24-26].

\section{Microbial fermentation}

Fermentation is the final step of the conversion of lignocelulosic biomass to produce bioethanol. Evaluation of bioethanol production by fermentation is of utmost importance to quantify the performance of the final process [1]. A variety of microorganisms (yeast, fungi and bacteria), and suitable technology implied for efficiency carbohydrates fermentation. Some of the microbes have ability to ferment both glucose and xylose [26-28]. A number of genetically engineered yeast and bacterial strains were reported for the production of bioethanol from different sugars using potential Saccharomyces, Pichia stipitis, Candida shehatae, Klebsiella oxytoca and Zymomonas mobilis strains $[2,24,29]$. Recently co-culturing and sequential use of yeast strains have been explored as promisingly, for the high-level bioethanol production [7,30,31]. Ethanologenic E. coli enhanced the yield of ethanol production using micro aeration process [7]. Genetically engineered Escherichia coli K011 was reported as to produce efficient ethanol from both pentose and hexose sugars [32]. Protoplasts fusant strains were also reported as glucose and xylose-fermenting yeast $[7,33]$.

\section{Future Work}

Efforts may be given to improve bioethanol production by developing genetically modified microorganisms and advance technology. Details cost analysis and economical feasibility of different bioconversion processes need to be studied at pilot scale for further large scale production of bioethanol from lignocellulosic biomass.

\section{References}

1. Sahu S (2016) Conversion of Cotton Gin Waste to Bioethanol: Pretreatment, Hydrolysis and Fermentation (Doctoral dissertation).
2. Rajendran R, Radhai R, Sundaram KS, Rajalakshmi V (2015) Utilization of cellulosic biomass as a substrate for the production of bioethanol. International Journal of Environmental Sciences 5(4): 743753.

3. Mtui Godliving YS (2009) Recent advances in pretreatment of lignocellulosic wastes and production of value added products. African Journal of Biotechnology 8(8): 1398-1415.

4. Pérez J, Munoz-Dorado J, De la Rubia T, Martinez J (2002) Biodegradation and biological treatments of cellulose, hemicellulose and lignin: an overview. Int Microbiol 5(2): 53-63.

5. Parani K, Eyini M (2010) Effect of co-fungal treatment on biodegradation of coffee pulp waste in solid state fermentation. Asian J Exp Biol Sci 1(2): 352-359.

6. Balat M (2011) Production of bioethanol from lignocellulosic materials via the biochemical pathway: A review. Energy Conversion and Managememt 52(2): 858-875.

7. Sahu S, Pramanik K (2015) Bioconversion of Cotton Gin Waste to Bioethanol. Environmental Microbial Biotechnology 45: 267-288.

8. Taherzadeh MJ, Karimi K (2008) Pretreatment of lignocellulosic wastes to improve ethanol and biogas production: A review. Int J Mol Sci 9(9): 1621-1651.

9. Nazarpour F, Abdullah DK, Abdullah N, Zamiri R (2013) Evaluation of biological pretreatment of rubber wood with white rot fungi for enzymatic hydrolysis. Materials 6(5): 2059-2073.

10.Sahu S, Krishna P (2017) Evaluating Fungal Mixed Culture for Pretreatment of Cotton Gin Waste to Bioethanol by Enzymatic Hydrolysis and Fermentation Using Co-Culture. Pol J Environ Stud 26(3): 1215-1223.

11. Gutierrez-Correa M, Tengerdy RP (1997) Production of cellulase on sugar cane bagasse by fungal mixed culture solid substrate fermentation. Biotechnology Letters 19(7): 665-667.

12. Kumar R, Mago G, Balan V, Wyman CE (2009) Physical and chemical characterizations of corn stover and poplar solids resulting from leading pretreatment technologies. Bioresour Technol 100(17): 39483962.

13. Marcolongo L, Ionata E, La Cara F, Amore A, Giacobbe S, et al. (2014) The effect of Pleurotus ostreatus arabinofuranosidase and its evolved variant in lignocellulosic biomasses conversion. Fungal Genet Biol 72: 162-167.

14. Sahu S, Pramanik (2015) Delignification of cotton gin waste and its optimization by using white rot fungus Pycnoporus cinnabarinus. Journal of Environmental Biology 36(3): 661-667.

15. Pant D, Adholeya A (2007) Enhanced production of ligninolytic enzymes and decolorization of molasses distillery wastewater by fungi under solid state fermentation. Biodegradation 18(5): 647-659.

16. Vivekanand V, Dwivedi P, Sharma A, Sabharwal N, Singh RP, et al. (2008) Enhanced delignification of mixed wood pulp by Aspergillus fumigatus laccase mediator system. World Journal of Microbiology and Biotechnology 24(12): 2799-2804.

17. Ojumu TV, Solomon BO, Betiku E, Layokun SK, Amigun B (2003) Cellulase Production by Aspergillus flavus Linn Isolate NSPR 101 fermented in sawdust, bagasse and corncob. African Journal of Biotechnology 2(6): 150-152.

18. Knežević A, Stajić M, Jovanović VM, Kovačević V, Ćilerdžić J, et al. (2016) Induction of wheat straw delignification by Trametes species. Scientific reports 6: 26529.

19. Kunamneni A, Ballesteros A, Plou FJ, Alcalde M (2007) Fungal laccase-a versatile enzyme for biotechnological applications. Applied microbiology 1: 233-245. 
20. Sindhu R, Kuttiraja M, Binod P, Janu KU, Sukumaran RK, et al. (2011) Dilute acid pretreatment and enzymatic saccharification of sugarcane tops for bioethanol production. Bioresource Technology 102(23): 10915-10921.

21. El-Zawawy WK, Ibrahim MM, Abdel-Fattah YR, Soliman NA Mahmoud MM (2011) Acid and enzyme hydrolysis to convert pretreated lignocellulosic materials into glucose for ethanol production. Carbohydrate polymers 84(3): 865-871.

22. Hu J, Arantes V, Saddler JN (2011) The enhancement of enzymatic hydrolysis of lignocellulosic substrates by the addition of accessory enzymes such as xylanase: is it an additive or synergistic effect?. Biotechnology for biofuels 4(1): 36 .

23. Devi MC, Kumar MS (2017) Production, optimization and partia purification of cellulase by Aspergillus niger fermented with paper and timber sawmill industrial wastes. Journal of microbiology and biotechnology research 2(1): 120-128.

24. Sun Y, Cheng J (2002) Hydrolysis of lignocellulosic materials for ethanol production: a review. Bioresource technology 83(1): 1-11.

25. Domingues FC, Queiroz JA, Cabral JMS, Fonseca LP (2001) Production of cellulases in batch culture using a mutant strain of Trichoderma reesei growing on soluble carbon source. Biotechnology Letters 23(10): 771-775.

26. Ryabova OB, Chmil OM, Sibirny AA (2003) Xylose and cellobiose fermentation to ethanol by the thermotolerant methylotrophic yeast Hansenula polymorpha. FEMS yeast research 4(2): 157-164.
27. Menon V, Prakash G, Prabhune A, Rao M (2010) Biocatalytic approach for the utilization of hemicellulose for ethanol production from agricultural residue using thermostable xylanase and thermotolerant yeast. Bioresource technology 101(14): 5366-5373.

28. Dogaris I, Mamma D, Kekos D (2013) Biotechnological production of ethanol from renewable resources by Neurospora crassa: an alternative to conventional yeast fermentations? Applied microbiology and biotechnology 97(4): 1457-1473.

29. Sarks C, Jin M, Sato TK, Balan V, Dale BE (2014) Studying the rapid bioconversion of lignocellulosic sugars into ethanol using high cell density fermentations with cell recycle. Biotechnology for biofuels $7(1): 73$.

30. Yadav KS, Naseeruddin S, Prashanthi GS, Sateesh L, Rao LV (2011) Bioethanol fermentation of concentrated rice straw hydrolysate using co-culture of Saccharomyces cerevisiae and Pichia stipitis. Bioresource technology 102(11): 6473-6478.

31. Fu N, Peiris P, Markham J, Bavor J (2009) A novel co-culture process with Zymomonas mobilis and Pichia stipitis for efficient ethanol production on glucose/xylose mixtures. Enzyme and Microbial Technology 45(3): 210-217.

32. Imamoglu E, Sukan FV (2014) The effects of single and combined cellulosic agro-waste substrates on bioethanol production. Fuel 134: 477-484.

33. Kumari R, Pramanik K (2012) Improved bioethanol production using fusants of Saccharomyces cerevisiae and xylose-fermenting yeasts. Applied biochemistry and biotechnology 167(4): 873-884.

\section{Your next submission with Juniper Publishers will reach you the below assets}

- Quality Editorial service

- Swift Peer Review

- Reprints availability

- E-prints Service

- Manuscript Podcast for convenient understanding

- Global attainment for your research

- Manuscript accessibility in different formats

( Pdf, E-pub, Full Text, Audio)

- Unceasing customer service

Track the below URL for one-step submission https://juniperpublishers.com/online-submission.php 